\title{
PHYSICAL-SPATIAL ASPECT IN LOCAL EXPRESSION OF TOWNSCAPE ON SAMIRONO YOGYAKARTA
}

\author{
${ }^{1}$ Leonardo Devin Setiawan, ${ }^{2}$ Ir. FX. Budiwidodo Pangarso, MSP \\ ${ }^{1}$ Student in the Bachelor's (S-1) Study Program in Architecture \\ at Parahyangan Catholic University \\ ${ }^{2}$ Senior lecturer in the Bachelor's (S-1) Study Program in Architecture \\ at Parahyangan Catholic University
}

\begin{abstract}
Cities change by time to time physically and non-physically. The city development produces a distinctive character even in the smallest urban creature. This distinctive character does not take quickly but is slowly and full of challenges.

Townscape is a visual impression of buildings arrangement, roads, and spaces those are expressed organically to form urban spaces. Therefore, a townscape that exists in an urban area is created on delevlopment or grows by unintentionally. Apart from that, the character of a townscape from one place is different from the other. The townscapes had been created and specific in each place.

The literatures for this research are: 'The Concise Townscape', 'The Aesthetic Townscape', and 'Road Form and Townscape'. The three literatures describe the existence of townscape in Europe and Japan. This is the basic knowledge in townscape and how it is applied in Indonesia, especially in the city of Yogyakarta. The urban space chosen in this research is Padukuhan Samirono.

Padukuhan Samirono is located in the north of Yogyakarta City and is very close to Gadjah Mada University and Negri Yogyakarta University. Padukuhan Samirono is known as an area that provides student accomodation. The community still stand fot maintaining their cultural habit such as gathering, cultural performances, and parades.

This study examines the Townscape in Padukuhan Samirono. The social and cultural activities expressed their locality as seen as in its townscape. The pictorial analysis method identify the elements of townscapes wich effects the urban space. By describing the elements of urban space with 7 factors: nature elements, space organization, mass, proportion, activity, carving, and streetscape, the local expression criteria of Padukuhan Samirono's can be formulated.

Based on observations, the local expression of townscape on Samirono changes into a modern form. This research attempts to enhance people's aprrectiation about townscape, especially townscape in Indonesia.
\end{abstract}

Key Words: townscape, pictorial analysis, Samirono, Javanese, locality

\section{EKSPRESI LOKALITAS PANORAMA BENTANG KOTA BERDASARKAN ASPEK FISIK-SPASIAL DI PADUKUHAN SAMIRONO}

\author{
${ }^{1}$ Leonardo Devin Setiawan, ${ }^{2}$ Ir. FX. Budiwidodo Pangarso, MSP \\ ${ }^{1}$ Mahasiswi S1 Program Studi Arsitektur Universitas Katolik Parahyangan \\ ${ }^{2}$ Dosen Pembimbing S1 Program Studi Arsitektur Universitas Katolik Parahyangan
}

\footnotetext{
${ }^{1}$ Corresponding Author: leoodevin@gmail.com
} 
Abstrak - Kota berubah dari waktu ke waktu secara aspek fisik maupun nonfisik. Berkembangnya kota menghasilkan karakter yang khas bahkan hingga lingkup terkecil di perkotaan. Pembentukan karakter ini tidak berlangsung cepat melainkan lambat dan penuh tantangan.

Panorama ruang kota adalah suatu impresi visual dari tatanan bangunan, jalan, ruang yang berekspresi secara organik membentuk ruang perkotaan. Oleh karena itu, sebuah townscape yang ada di perkotaan tercipta secara sengaja dirancang atau tumbuh secara tidak sengaja. Terlepas dari itu, karakter townscape suatu tempat berbeda dengan tempat lain sehingga townscape yang tercipta sangatlah banyak dan spesifik di setiap tempat.

Kajian literatur yang dipakai pada penelitian ini antara lain: 'The Concise Townscape', 'The Aesthetic Townscape', dan 'Road Form and Townscape'. Ketiga literatur tersebut membahas eksistensi panorama bentang kota yang ada di Eropa dan Jepang. Hal ini merupakan dasar pengetahuan pada penelitian panorama bentang kota yang diterapkan di Indonesia, khususnya pada Kota Yogyakarta. Ruang perkotaan yang dipilih penulis sebagai objek penelitian adalah Padukuhan Samirono.

Padukuhan Samirono terletak di sebelah utara Kota Yogyakarta dan berjarak sangat dekat dengan Universitas Gadjah Mada dan Universitas Negri Yogyakarta. Padukuhan Samirono dikenal sebagai kampung kota yang menyediakan jasa indekos. Masyarakat tetap berusaha mempertahakan nilai-nilai kebudayaan seperti berkumpul, pentas budaya, dan pawai.

Penelitian ini mengkaji panorama bentang kota yang terlihat di Padukuhan Samirono. Kegiatan sosial dan budaya yang masih dilestarikan berpengaruh pada ekspresi lokalitas yang terlihat pada panorama bentang kota. Metode yang digunakan adalah pictorial analysis untuk mengidentifikasi elemen panorama bentang kota yang berpengaruh signifikan terhadap nuansa ruang kota. Setelah menguraikan elemen ruang kota, dapat dirumuskan kriteria ekspresi lokalitas di Padukuhan Samirono.

Berdasarkan pengamatan, ditemukan adanya transformasi ekspresi lokalitas dalam rupa modern. Hal ini terlihat pada elemen perkotaan yang mengambil rupa bentuk sekitar seperti plengkung. Penelitian ini diharapkan dapat meningkatkan tingkat apresiasi pembaca terhadap panorama bentang kota khususnya pada kota-kota di Indonesia.

Kata Kunci: panorama bentang kota, townscape, pictorial analysis, Samirono, masyarakat Jawa, lokalitas

\section{PENDAHULUAN}

Perkembangan globalisasi berpengaruh pada gaya hidup perkotaan dan melunturkan budaya lokal. Globalisasi bergerak secara masif dan tak terelakkan, mengarahkan elemen citra visual secara global untuk serupa dan monoton. Identitas yang terbentuk dalam panorama bentang kota dapat lambat laun hilang dan nilai tempat yang seharusnya ada menjadi tereduksi. Padahal, citra kota bercitra lokal merupakan salah satu warisan kebudayaan yang sangat disayangkan dan tidak tergantikan bila di kemudian hari hilang.

Penelitian ini berusaha untuk mendokumentasikan panorama bentang kota pada sebuah kampung kota. Di Indonesia, penelitian mengenai panorama bentang kota masih berjumlah minim. Penelitian ini hendak memperluas wawasan pembaca melalui pembahasan literatur dan kawasan. Dengan begitu membangun kesadaran introspeksi dan proyeksi perkembangan panorama bentang kota di Indonesia. Literatur yang digunakan dalam penelitian panorama bentang kota ini antara lain: buku 'The Concise Townscape' oleh Gordon Cullen, 'The Aesthetic Townscape' oleh Yoshinobu Ashihara, dan buku 'Road Form and Townscape' oleh Jim McCluskey.

Padukuhan Samirono dipilih sebagai objek penelitian ini sebagai sampel kampung kota yang masih menjunjung budaya setempat untuk dilestarikan. Kebutuhan atas ruang sosial mengakibatkan townscape yang unik pada kawasan permukiman. Terdapat beberapa ruang publik untuk menyokong kegiatan masyarakat yang sering berkumpul dan menggelar pentas budaya.

\subsection{PERTANYAAN PENELITIAN}

1. Bagaimana peran elemen perkotaan membentuk impresi panorama bentang kota di Padukuhan Samirono? 
2. Bagaimana rupa ekspresi lokalitas pada panorama bentang kota di Padukuhan Samirono?

\subsection{TUJUAN PENELITIAN}

1. Memahami dan memperdalam definisi panorama bentang kota atau townscape terutama menurut buku 'The Concise Townscape', 'The Aesthetic Townscape', dan 'Road Form and Townscape'

2. ajian literatur dari 'The Concise Townscape', 'The Aesthetic Townscape', dan 'Road Form and Townscape' pada kota di Indonesia, khususnya di Pulau Jawa.

3. Memahami implementasi ekpresi lokalitas terhadap townscape di sebuah kampung kota.

\subsection{MANFAAT PENELITIAN}

1. Peneliti: dapat menambah wawasan mengenai panorama bentang kota beserta elemenelemennya baik fisik maupun nonfisik pada kota-kota di Indonesia.

2. Lembaga pemerintah, arsitek, perencana wilayah dan kota: masukan untuk pengembangan perancangan panorama bentang kota yang indah dan selaras dengan kultur setempat.

3. Kontribusi wawasan untuk perancangan karya arsitektur ke depannya dengan fungsi serupa.

\subsection{RUANG LINGKUP PENELITIAN}

1. Lingkup penelitian dipaparkan secara teks deskriptif dan visual dari objek penelitian yang diobservasi secara daring.

2. Kawasan yang diteliti terbatas pada Padukuhan Samirono, Desa Caturtunggal, Kecamatan Depok, Kabupaten Sleman, Daerah Istimewa Yogyakarta, 55281.

3. Kajian literatur dari 'The Concise Townscape', 'The Aesthetic Townscape', dan 'Road Form and Townscape' di Indonesia, khususnya di Pulau Jawa.

\subsection{OBJEK PENELITIAN}

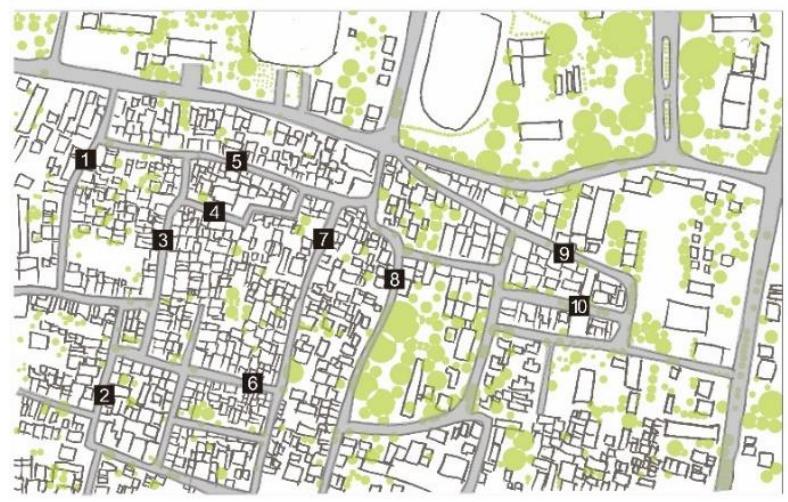

Gambar 1. Peta visi serial pada koridor Padukuhan Samirono 


\section{KAJIAN TEORI}

\subsection{POTENSI EKSPRESI DAN CITRA PANORAMA BENTANG KOTA}

\subsubsection{EKSPRESI}

Berdasarkan definisi dari KBBI, ekspresi adalah pengungkapan atau proses menyatakan sesuatu. Ekspresi secara umum dikaitkan dengan wajah subjek yang memperlihatkan emosinya. Bani Noor Muchamad dan Ikaputra dalam jurnalnya berusaha menyimpulkan definisi ekspresi dari beberapa sumber. Ekspresi memiliki kedekatan makna dengan 'proses' berkomunikasi . Lebih lanjut, ekspresi merupakan upaya membangun persepsi agar terjadi kesamaan maksud (pesan) antara pihak pemberi pesan kepada penerima. Dalam penyampaian tersebut dibutuhkan media sebagai perantara diantaranya.

\subsubsection{EKSPRESI LOKALITAS}

Ekspresi lokalitas dapat disimpulkan sebagai hasil persepsi terhadap objek yang yang secara sengaja maupun tidak sengaja memiliki rasa unsur kultur setempat. Di Indonesia, lokalitas dikaitkan dengan suku bangsa dengan berbagai macam atributnya. Ekspresi lokalitas memiliki pesan mendasar berupa cara pandang hidup masyarakat lokal.

\subsubsection{TOWNSCAPE MENURUT BUKU 'THE CONCISE TOWNSCAPE'}

Visi serial adalah Cara untuk mengidentifikasi townscape suatu tempat diperlukan visi yang menyeluruh dari berbagai sudut pandang. Hal ini dapat dilakukan dalam proses sketsa untuk memahami kedalaman ruang dan panoramic experience.

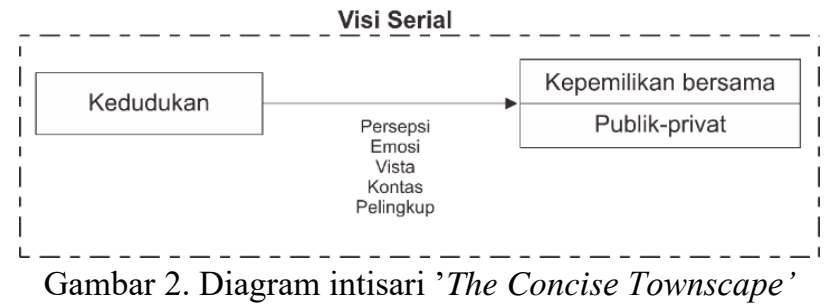

\subsubsection{TOWNSCAPE MENURUT BUKU 'THE AESTHETIC TOWNSCAPE}

Buku ini membahas tentang perbedaan pandangan terjadap ruang pada budaya barat dan budaya timur (Jepang). Buku ini juga membahas tentang proporsi ideal yaitu $\mathrm{D} / \mathrm{H}=1$, yaitu lebar jalan sama dengan tinggi bangunan. Proporsi tertentu dapat menciptakan persepsi ruang tertentu. Buku ini juga membahas mengenai elemen primer dan elemen sekunder yang berpengaruh pada panorama bentang kota. Fungsi dari elemen sekunder salah satuya sebagai penyemarak elemen primer.

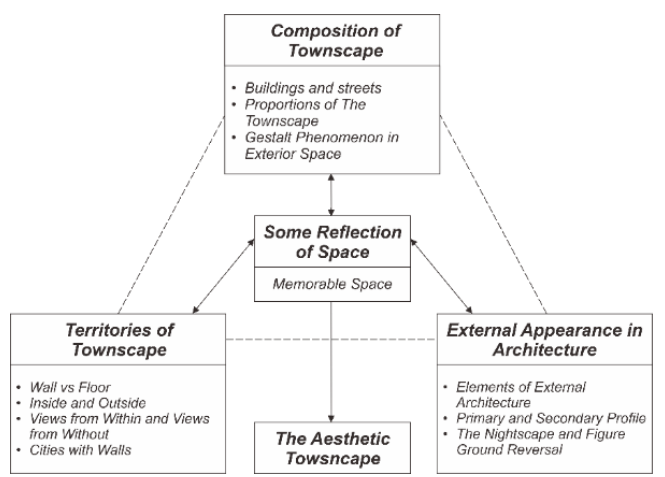

Gambar 3. Diagram Intisari 'The Aesthetic Townscape' 


\subsubsection{TOWNSCAPE MENURUT BUKU 'ROAD FORM AND TOWNSCAPE'}

Buku ini membahas mengenai elemen-elemen townscape, salah satunya berbagai bentuk jalan menimbulkan berbagai macam persepsi pada jalan dan bangunan yang ada pada jalan tersebut. Elemen material, permukaan material, dan pembatas dapat memberikan informasi tertentu atau bagian dari elemen dekoratif.

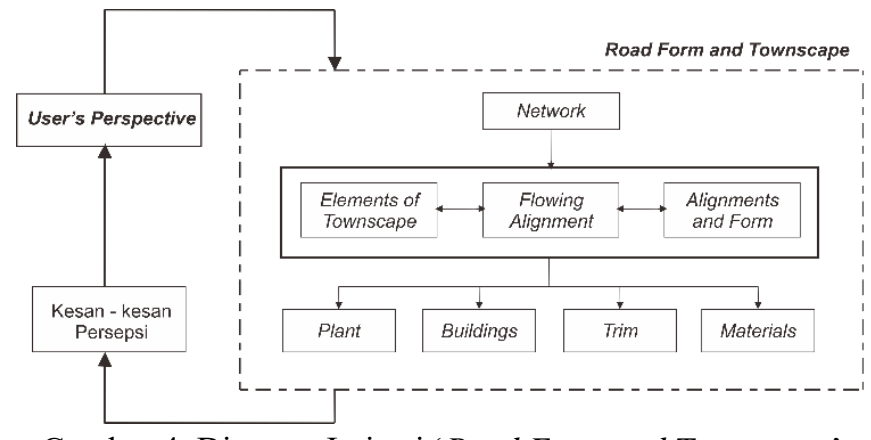

Gambar 4. Diagram Intisari 'Road Form and Townscape'

\subsection{ESTETIKA JAWA}

Ruang perkotaan yang tercipta tanpa adanya kultur yang terekspresikanm secara visual akan menghasilkan ruang perkotaan yang sama di berbagai tempat. Kultur-kultur itu hadir dalam berbagai bentuk sederhana dari marka jalan, pola lantai, dan railing jalan yang unik dan menyatakan identitasnya. Elemen fisik-spasial yang ada merupakan cerminan berbagai kejadian-kejadian, kebiasaan, kebutuhan masyarakat kota terhadap apa yang dibutuhkan pada kota tersebut. Elemen-elemen ruang perkotaan seperti jalan, bangunan, hingga elemen terkecil berupa marka jalan membentuk harmoni yang khas. Ruang perkotaan merupakan bagian yang tidak terpisahkan dari keestetikaan yang dibentuk oleh masyarakat. Keestetikan disimpulkan terdiri dari 3 perkara utama yaitu kebaikan (goodness), kebenaran (truth), dan keindahan (beauty).

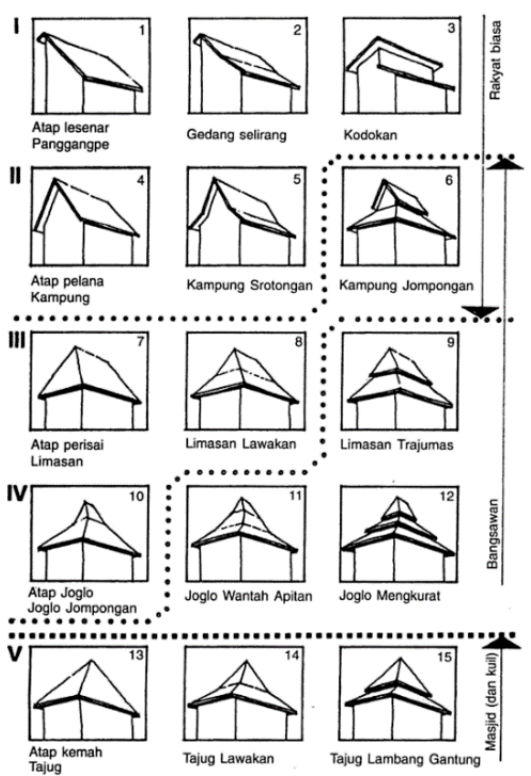

Gambar 5. Bentuk atap dan kedudukan Sosial (Sumber: Heinz Frick, 1997) 
Agus Sachari dalam bukunya 'Estetika: Makna, Simbol, dan Daya' merangkum pendapat Budiono Herusutanto dalam tulisannya yang berjudul 'Simbolisme dalam Budaya Jawa' tentang masyarakat Jawa terkait keestetikaan yaitu:

1. Bersifat kontemplatif transedental

Pengungkapan keindahan melalui perenungan (kontemplasi), syukur dan penghayatan mendalam kepada Tuhan YME, raja, atau alam.

2. Bersifat simbolistik

Setiap tindakan bereskpresi selalu bermakna simbolik

3. Bersifat filosofis

Setiap tindakan selalu didasarkan sikap tertentu yang dimuat pada berbagai ungkapan hidup

Secara lebih lanjut, masyarakat Jawa lebih menyukai penyusunan yang simetris (berarti keseimbangan atau kodrat alam), serta mengenal sistem hirarki dalam lapisan masyarakat. Hirarki tersebut terdapat pada pembagian agama hingga bentuk arsitektur bangunan (secara mudah dapat terlihat dari atap). Ornamen-ornamen pada bangunan arsitektur Jawa juga memiliki nilai filosofis tertentu yang berkaitan dengan keindahan, keseimbangan, dan doa perlindungan.

\subsection{TIPOLOGI LANDMARK KOTA YOGYAKARTA}

Kota Yogyakarta dengan kebudayaan yang telah mengakar sejak masa lampau terlihat pada penataan kota dan elemen dekoratif kota. Landmark-landmark merupakan cara sebuah kota menggambarkan kepribadian masyarakat kota, begitu pula masyarakat kota menggambarkan kepribadian kotanya. Berikut merupakan landmark-landmark yang ada di Kota Yogyakarta dan berada di sekitar jalan sehingga melekat pada kehidupan keseharian masyarakat.

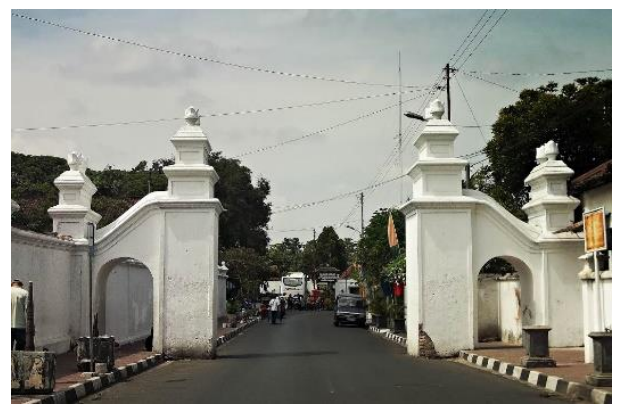

Gambar 6. Plengkung Jogo Suro

(Sumber: mapio.net)

\section{METODE PEMBAHASAN}

Berdasarkan pemahaman dari literatur-literatur seperti 'The Concise Townscape' oleh Gordon Cullen, 'The Aesthetic Townscape' oleh Yoshinobu Ashihara, dan buku 'Road Form and Townscape' oleh Jim McCluskey, dapat ditarik cara atau upaya pengungkapan fenomena panorama bentang kota. Simpul dan koridor merupakan objek potensial sebagai substansi tipe ruang kota yang hendak ditelaah.

Penentuan titik-titik simpul dan koridor didasari oleh pola keunikan dan sebagai sampel dari panorama bentang kota yang ada. Proses pembahasan terbagi menjadi empat tahap yaitu tahap penentuan lokasi titik pengamatan, tahap deskripsi observasi melalui pictorial analysis, pemaparan tanggapan dari narasumber, dan tahap penarikan kesimpulan. 
Objek pengamatan dibagi menjadi tiga buah segmen menjadi segmen A, segmen B, dan segmen C. Cara untuk melakukan visi serial yaitu dengan melakukan sketsa dari panorama bentang kota yang berisi elemen-elemen fisik statis seperti bangunan hingga elemen-elemen dinamis seperti aktivitas, suasana, dan kendaraan. Pola-pola tersebut terekam dan ikut tergambarkan pada sketsa-sketsa visi serial titik-titik tersebut.

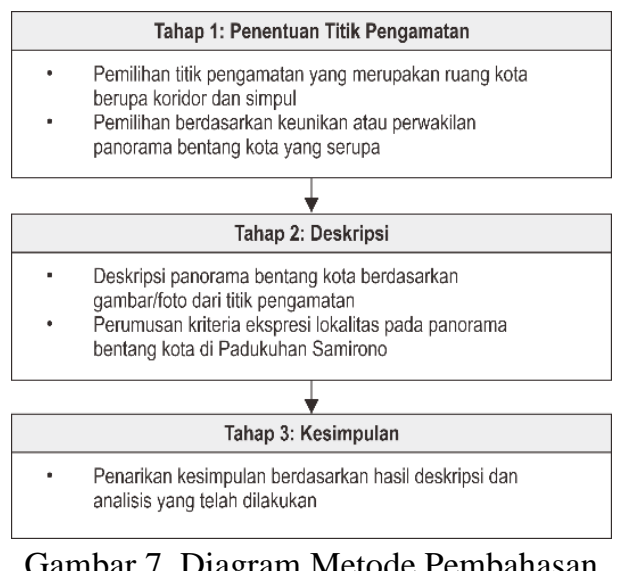

\section{ANALISIS}

\subsection{ANALISIS FAKTOR FISIK-SPASIAL SEBAGAI KOMPONEN PEMBENTUK} EKSPRESI LOKALITAS DI PADUKUHAN SAMIRONO

\subsubsection{PARAMETER ANALISIS PANORAMA BENTANG KOTA}

Dalam melakukan penilaian terhadap elemen-elemen ruang perkotaan, parameter digunakan untuk memudahkan pengelompokan dan membandingkan dengan skala. Melalui skala, penilaian akan lebih tajam dengan derajat pengukuran. Indikator penilaian (analysis unit) terdiri dari 7 buah faktor, yaitu elemen natural (terdiri dari vegetasi dan waterscape), proporsi, massa, space organization, aktivitas (terdiri dari formal dan informal), carving, dan streetscape. Ketujuh faktor tersebut masing-masing dikajikan terhadap lima elemen pokok perkotaan (observation unit) yang mewakili tampilan visual ruang perkotaan secara general seperti jalan, fasad bangunan, trotoar, ruang terbuka, dan monumen.

Tabel 1. Parameter Deskripsi Ruang Kota

\begin{tabular}{|c|c|c|c|c|c|c|c|c|c|}
\hline & \multirow{2}{*}{\multicolumn{2}{|c|}{$\begin{array}{c}\text { Eleme } \\
\mathrm{n} \\
\text { Natura } \\
1 \\
\end{array}$}} & \multirow{3}{*}{$\begin{array}{c}\text { Space } \\
\text { Organizati } \\
\text { on }\end{array}$} & \multirow{3}{*}{$\begin{array}{c}\text { Mass } \\
\text { a }\end{array}$} & \multirow{3}{*}{ Proporsi } & \multirow{2}{*}{\multicolumn{2}{|c|}{$\begin{array}{c}\text { Aktivit } \\
\text { as }\end{array}$}} & \multirow{3}{*}{$\begin{array}{c}\text { Carvin } \\
g\end{array}$} & \multirow{3}{*}{ Street-scape } \\
\hline & & & & & & & & & \\
\hline & $\mathrm{V}$ & $\mathrm{W}$ & & & & $\mathrm{F}$ & I & & \\
\hline \multicolumn{10}{|l|}{ Jalan } \\
\hline \multicolumn{10}{|l|}{$\begin{array}{c}\text { Fasad } \\
\text { Bangunan }\end{array}$} \\
\hline \multicolumn{10}{|l|}{ Trotoar } \\
\hline \multicolumn{10}{|l|}{$\begin{array}{c}\text { Ruang } \\
\text { Terbuka } \\
\end{array}$} \\
\hline Monumen & & & & & & & & & \\
\hline
\end{tabular}

Keterangan: (V) Vegetasi, (W) Waterscape, (F) Formal, dan (I) Informal 
Parameter ini bersifat subjektif serta universal sehingga dapat digunakan pada berbagai objek studi. Setiap kolom akan diisi dengan skala angka untuk dapat dibandingkan satu sama lain. Tidak semua 5 elemen pokok perkotaan dimiliki oleh masing-masing ruang perkotaan, sehingga parameter digunakan secara adaptif terhadap masing-masing ruang perkotaan.

\subsubsection{ANALISIS RUANG KOTA TITIK A.1.}

Tabel 2. Analisis Ruang Kota Titik A.1.

\begin{tabular}{|c|c|c|c|c|c|c|c|c|c|}
\hline & \multicolumn{2}{|c|}{$\begin{array}{c}\text { Eleme } \\
\mathrm{n} \\
\text { Natura } \\
1 \\
\end{array}$} & \multirow[t]{2}{*}{$\begin{array}{c}\text { Space } \\
\text { Organizati } \\
\text { on }\end{array}$} & \multirow[t]{2}{*}{$\begin{array}{c}\text { Mass } \\
\text { a }\end{array}$} & \multirow[t]{2}{*}{ Proporsi } & \multicolumn{2}{|c|}{$\begin{array}{c}\text { Aktivit } \\
\text { as }\end{array}$} & \multirow[t]{2}{*}{$\begin{array}{c}\text { Carvin } \\
\quad g\end{array}$} & \multirow[t]{2}{*}{ Street-scape } \\
\hline & $\mathrm{V}$ & W & & & & $\mathrm{F}$ & I & & \\
\hline Jalan & $\begin{array}{l}+ \\
2\end{array}$ & -2 & +1 & +1 & -1 & 0 & -1 & +2 & +1 \\
\hline $\begin{array}{c}\text { Fasad } \\
\text { Banguna } \\
\mathrm{n}\end{array}$ & $\begin{array}{l}+ \\
1\end{array}$ & & & +1 & & -2 & -2 & +2 & 0 \\
\hline Trotoar & & & & & & & & & \\
\hline $\begin{array}{c}\text { Ruang } \\
\text { Terbuka }\end{array}$ & & & & & & & & & \\
\hline$\underset{n}{\text { Monume }}$ & & & & & & & & & \\
\hline
\end{tabular}

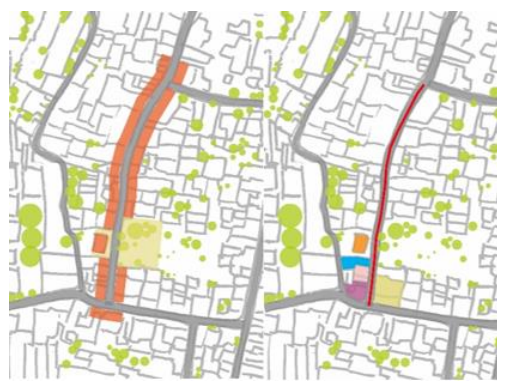

Gambar 8. Space Organization dan Massa pada Titik A.1.

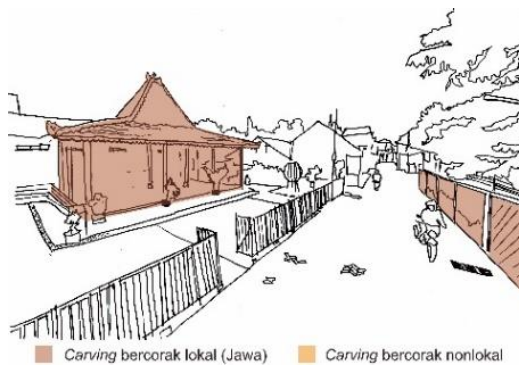

Gambar 9. Carving pada Titik A.1.

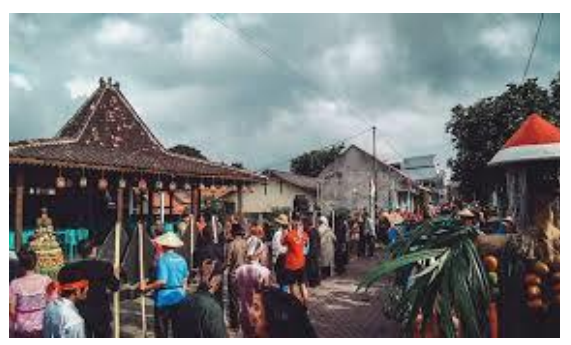

Gambar 10. Aktivitas Kluwung pada Titik A.1.

Pemakaman umum menjadi area penghijauan yang telah ada sejak lama dan meningkatkan kualitas visual pada Jalan Anggrek. Letak pemakaman yang berada berseberangan dengan Balai Budaya Samirono menciptakan kontras pada Jalan Anggrek dan menjadi bagian dari view dari arah dalam balai ke arah jalan.

Kedudukan Balai Budaya Samirono dan ruang terbuka di muka bangunannya merupakan ruang publik dengan fleksibilitas tinggi dan merupakan ruang terbuka yang semioutdoor. Tidak menutup kemungkinan bahwa aktivitas publik yang berpusat di Balai Budaya Samirono dapat tumpah ruah ke jalan.

Keberadaan Balai Budaya Samirono dan pemakaman mengakibatkan variasi kepadatan massa yang mayoritas padat kemudian renggang. Perbedaan tersebut cukup kontras dan menghasilkan pengalaman ruang jalan yang khas pada koridor Jalan Anggrek. 
Pada waktu pengamatan, tidak ada aktivitas komunitas pada Balai Budaya Samirono atau aktivitas tertenu pada titik pengamatan, hanya terdapat beberapa pengendara motor yang melintas. Aktivitas komunitas dilakukan pada malam hari dan rutin saat hari-hari tertentu. Terlihat beberapa meja diletakkan di depan rumah, menandakan adanya bekas aktivitas usaha rumah tangga seperti menghidangkan makan atau minum, serta kemungkinan hanya aktif pada jam-jam tertentu.

Aktivitas Kluwung Budaya Kampung yang berpusat pada Balai Budaya Samirono berpengaruh secara signifikan terhadap panorama bentang kota di Padukuhan Samirono. Keberadaan aktivitas tersebut secara cepat mengubah wajah panorama bentang kota menjadi meriah dan emosional.

\subsubsection{ANALISIS RUANG KOTA TITIK A.2.}

Tabel 3. Analisis Ruang Kota Titik A.2.

\begin{tabular}{|c|c|c|c|c|c|c|c|c|c|}
\hline & \multicolumn{2}{|c|}{$\begin{array}{c}\text { Eleme } \\
\mathrm{n} \\
\text { Natura } \\
1 \\
\end{array}$} & \multirow[t]{2}{*}{$\begin{array}{c}\text { Space } \\
\text { Organizati } \\
\text { on }\end{array}$} & \multirow[t]{2}{*}{$\begin{array}{c}\text { Mass } \\
\text { a }\end{array}$} & \multirow[t]{2}{*}{ Proporsi } & \multicolumn{2}{|c|}{$\begin{array}{c}\text { Aktivit } \\
\text { as }\end{array}$} & \multirow[t]{2}{*}{$\begin{array}{c}\text { Carvin } \\
\quad g\end{array}$} & \multirow[t]{2}{*}{$\begin{array}{l}\text { Street- } \\
\text { scape }\end{array}$} \\
\hline & $\mathrm{V}$ & $\mathrm{W}$ & & & & $\mathrm{F}$ & I & & \\
\hline Jalan & $\begin{array}{l}+ \\
1\end{array}$ & -2 & -1 & +1 & +1 & -2 & -1 & +1 & +1 \\
\hline $\begin{array}{c}\text { Fasad } \\
\text { Bangunan }\end{array}$ & $\begin{array}{l}+ \\
1\end{array}$ & & & +1 & & -2 & -2 & 0 & 0 \\
\hline Trotoar & & & & & & & & & \\
\hline Ruang Terbuk & & & & & & & & & \\
\hline Monumen & & & & & & & & & \\
\hline
\end{tabular}
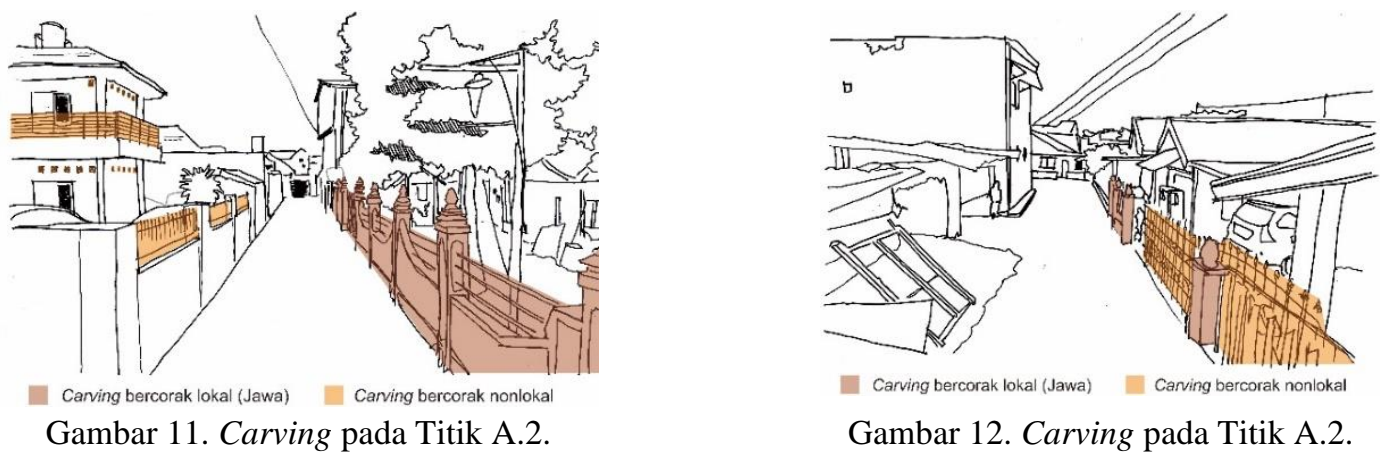

Gambar 12. Carving pada Titik A.2.

Proporsi pada Jalan Menur cukup ditentukan oleh pagar sebagai penentu karena bangunan cukup mundur dari garis koridor jalan. Terdapat beberapa bangunan yang berada langsung bertepatan dengan koridor jalan sehingga langsung mempengaruhi proporsi secara drastis dari dominan jalan menjadi dominan massa bangunan.

Carving terbentuk dari repetisi pagar serta railing balkon. Pagar-pagar turut mengadopsi bentuk-bentuk tradisional Jawa seperti kebenan dan plengkung. Bentuk tersebut turut dipadukan dengan elemen modern seperti baja ulir hingga membentuk keserasian.

Streetscape yang ada terdiri dari lampu jalan dan pagar-pagar yang terbuat dari dinding dengan variasi ketinggian. Bentuk pagar yang merupakan perpaduan vertikal dan horizontal yang berepetisi membentuk kesan perbedaan kaveling dan jalan terjadi sangat jelas. 


\subsubsection{ANALISIS RUANG KOTA TITIK A.3.}

Tabel 4. Analisis Ruang Kota Titik A.3.

\begin{tabular}{|c|c|c|c|c|c|c|c|c|c|}
\hline & \multicolumn{2}{|c|}{$\begin{array}{l}\text { Elemen } \\
\text { Natural }\end{array}$} & \multirow{2}{*}{$\begin{array}{c}\text { Space } \\
\text { Organizati } \\
\text { on }\end{array}$} & \multirow{2}{*}{ Massa } & \multirow{2}{*}{ Proporsi } & \multicolumn{2}{|c|}{ Aktivitas } & \multirow{2}{*}{ Carving } & \multirow{2}{*}{$\begin{array}{l}\text { Street- } \\
\text { scape }\end{array}$} \\
\hline & $\mathrm{V}$ & $\mathrm{W}$ & & & & $\mathrm{F}$ & I & & \\
\hline Jalan & $\begin{array}{l}+ \\
2\end{array}$ & -2 & 0 & +2 & -1 & 0 & 0 & +1 & 0 \\
\hline $\begin{array}{c}\text { Fasad } \\
\text { Banguna } \\
\mathrm{n}\end{array}$ & $\begin{array}{l}+ \\
2\end{array}$ & & & +2 & & 0 & 0 & +1 & -1 \\
\hline Trotoar & & & & & & & & & \\
\hline $\begin{array}{l}\text { Ruang } \\
\text { Terbuka }\end{array}$ & & & & & & & & & \\
\hline $\begin{array}{c}\text { Monume } \\
\mathrm{n}\end{array}$ & & & & & & & & & \\
\hline
\end{tabular}

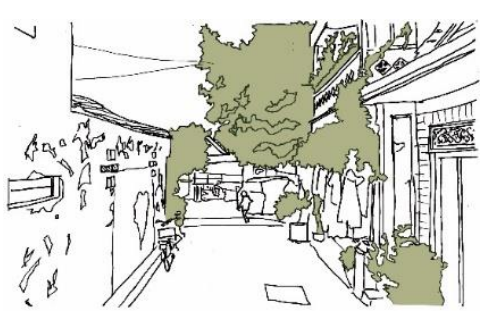

Gambar 13. Vegetasi pada Titik A.3.

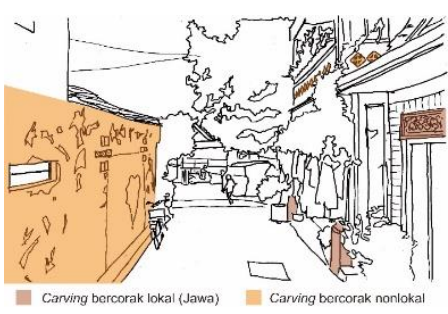

Gambar 14. Carving pada Titik A.3.

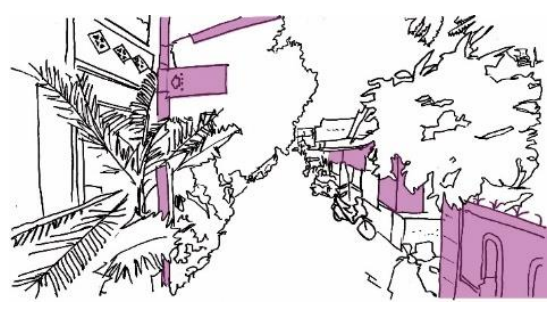

Gambar 15. Streetscape pada Titik

A.3.

Keberadaan elemen natural, khususya vegetasi sangat cukup mendominasi terutama pada persimpangan sehingga indah secara visual. Vegetasi menciptakan sebuah framing yang kuat sekaligus cukup menutupi fasad bangunan yang ada.

Mayoritas bangunan terdiri dari satu dan dua lantai. Pada Jalan Mawar, bangunan memiliki bentuk atap yang lebih rendah di bagian depan sehingga berpengaruh pada proporsi jalan.

Terdapat carving yang terbentuk dari kerawang, ventilasi dari kayu, dan mural yang terdapat pada dinding. Ventilasi yang berada di atas pintu salah satu rumah terbuat dari kayu dengan ukiran motif flora. Meski tidak secara langsung menggunakan motif-motif tradisional dari rumah tradisional joglo, namun tetap menggunakan motif flora. Carving yang terbentuk dari mural yang terdapat pada dinding berupa gambar figur dan kartun imajiner yang tidak berciri lokal (Jawa).

Terdapat beberapa streetscape pada titik pengamatan A.3. berupa spanduk usaha, pagar, tiang listrik, dan penunjuk jalan. Penunjuk jalan ini mengarahkan kepada Balai Budaya Samirono, Taman Pendidikan Al-Quran, Masjid Al-Ihklash dan Pemakaman Samirono. Penunjuk jalan tersebut berwarna hijau terang dan kontras dengan vegetasi di belakangnya sehingga terlihat jelas. Streetscape pada Titik A.3. tidak menunjukan rupa lokalitas sama sekali. 


\subsubsection{ANALISIS RUANG KOTA TITIK B.1.}

Tabel 5. Analisis Ruang Kota Titik B.1.

\begin{tabular}{|c|c|c|c|c|c|c|c|c|c|}
\hline & \multicolumn{2}{|c|}{$\begin{array}{c}\text { Eleme } \\
\mathrm{n} \\
\text { Natura } \\
1 \\
\end{array}$} & \multirow[t]{2}{*}{$\begin{array}{c}\text { Space } \\
\text { Organizati } \\
\text { on }\end{array}$} & \multirow[t]{2}{*}{$\begin{array}{c}\text { Mass } \\
\text { a }\end{array}$} & \multirow[t]{2}{*}{ Proporsi } & \multicolumn{2}{|c|}{$\begin{array}{c}\text { Aktivit } \\
\text { as }\end{array}$} & \multirow[t]{2}{*}{$\begin{array}{c}\text { Carvin } \\
g\end{array}$} & \multirow[t]{2}{*}{ Street-scape } \\
\hline & $\mathrm{V}$ & $\mathrm{W}$ & & & & $\mathrm{F}$ & I & & \\
\hline Jalan & 0 & -2 & +1 & +2 & 0 & 0 & -1 & +1 & 0 \\
\hline $\begin{array}{c}\text { Fasad } \\
\text { Banguna } \\
\mathrm{n}\end{array}$ & 0 & & & +2 & & -2 & -2 & 0 & 0 \\
\hline Trotoar & & & & & & & & & \\
\hline $\begin{array}{c}\text { Ruang } \\
\text { Terbuka }\end{array}$ & & & & & & & & & \\
\hline $\begin{array}{c}\text { Monume } \\
\mathrm{n}\end{array}$ & & & & & & & & & \\
\hline
\end{tabular}

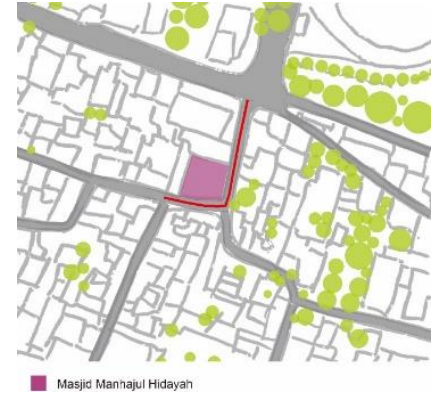

Gambar 16. Space Organization pada Titik B.1.

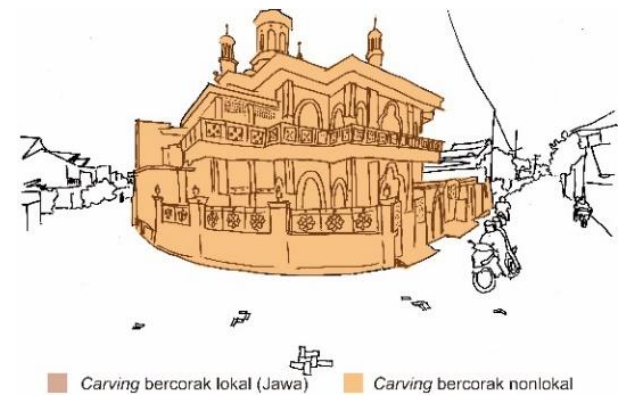

Gambar 18. Carving pada Titik B.1.

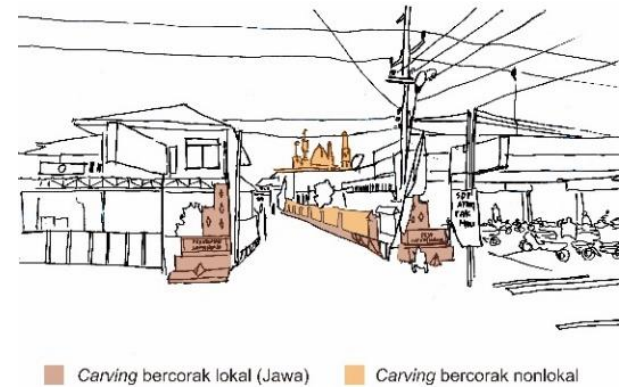

Gambar 17. Carving pada Titik B.1.

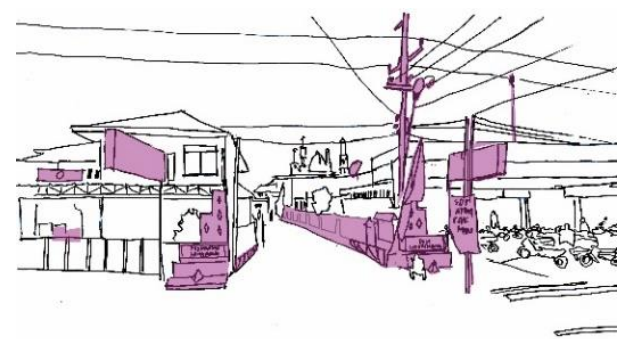

Gambar 19. Streetscape pada Titik B.1.

Ruang terbuka hanya dimiliki privat dan sangat terbatas. Bangunan Manhajul Hidayah terletak pada posisi strategis berupa kaveling hook sehingga terlihat dengan jelas bagian depan dan samping bangunan. Keberadaan Masjid Manhajul Hidayah sebagai bangunan publik menjadi mudah terlihat dan kesan inklusif. Bangunan masjid juga merespon jalan dengan komposisi fasad dan tembok yang berdiri mengikuti kelengkungan jalan. Titik pengamatan B.1. dapat dikategorikan menjadi strategic space, didukung pula akses yang mudah dari Jalan Colombo.

Tinggi bangunan cenderung setara antara sisi koridor timur dan barat dengan tinggi bangunan lebih besar daripada koridor jalan. Bangunan masjid menjadi kontras dengan 
keteraturannya dibanding massa-massa lain yang cenderung kurang teratur. Tinggi masa bangunan dengan lebar jalan relatif sama.

Aktivitas yang terlihat berupa lalu lalang kendaraan bermotor saja. Sebagai tempat ibadah, Masjid Manhajul Hidayah hanya aktif pada waktu-waktu tertentu. Pagar Masjid yang cenderung masif mengindikasikan aktivitas masjid dicegah untuk tumpah ruah ke jalan.

Bangunan Masjid Manhajul Hidayah memiliki carving yang tercipta dari bentukbentuk geometris. Secara keseluruhan, arsitektur bangunan masjid tidak mengadopsi bentuk arsitektur jawa untuk bangunan masjid melainkan adaptasi dari bentuk arsitektur masjidmasjid di Timur Tengah. Hal ini menunjukkan adanya pengaruh tren arsitektur masjid yang juga turut melanda Padukuhan Samirono.

Pada Titik B.1. terdapat beberapa streetscape berupa signage usaha, ting listrik, spanduk-spanduk iklan dan pagar. Streetscape ini kebanyakan bertujuan komersial. Keberadaan gapura bertujuan sebagai penanda batas wilayah teritorial. Gapura yang berada di permulaan Jalan Bougenville identik dengan gapura yang berada di Jalan Anggrek. Keberadaan gapura mulai samar figurnya akibat bertumpukkan dengan berbagai streetscape lain.

\subsubsection{ANALISIS RUANG KOTA TITIK B.2.}

Tabel 6. Analisis Ruang Kota Titik B.2.

\begin{tabular}{|c|c|c|c|c|c|c|c|c|c|}
\hline & \multicolumn{2}{|c|}{$\begin{array}{l}\text { Elemen } \\
\text { Natural }\end{array}$} & \multirow{2}{*}{$\begin{array}{c}\text { Space } \\
\text { Organizati } \\
\text { on }\end{array}$} & \multirow{2}{*}{$\begin{array}{c}\text { Mass } \\
\text { a }\end{array}$} & \multirow{2}{*}{ Proporsi } & \multicolumn{2}{|c|}{$\begin{array}{c}\text { Aktivit } \\
\text { as }\end{array}$} & \multirow{2}{*}{ Carving } & \multirow{2}{*}{ Street-scape } \\
\hline & $\mathrm{V}$ & $\mathrm{W}$ & & & & $\mathrm{F}$ & I & & \\
\hline Jalan & $\begin{array}{l}+ \\
2\end{array}$ & -2 & 0 & 0 & 0 & 0 & -1 & 0 & +1 \\
\hline $\begin{array}{c}\text { Fasad } \\
\text { Banguna } \\
\mathrm{n}\end{array}$ & $\begin{array}{l}+ \\
1\end{array}$ & & & +1 & & -2 & -2 & 0 & +1 \\
\hline \multicolumn{10}{|l|}{ Trotoar } \\
\hline \multicolumn{10}{|l|}{$\begin{array}{c}\text { Ruang } \\
\text { Terbuka }\end{array}$} \\
\hline $\begin{array}{c}\text { Monume } \\
\mathrm{n}\end{array}$ & & & & & & & & & \\
\hline
\end{tabular}

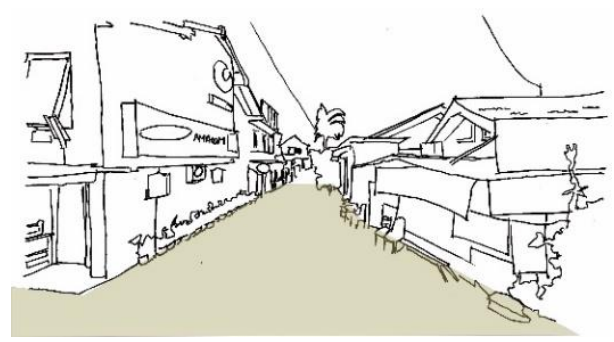

Gambar 20. Aktivitas pada Titik B.2.

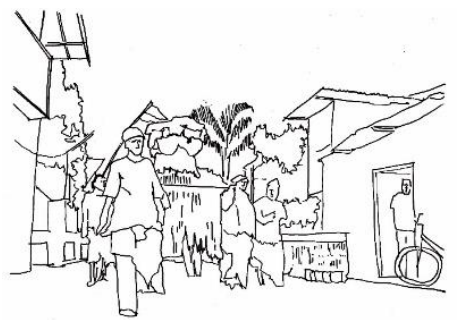

Gambar 21. Aktivitas pada Titik B.2. 


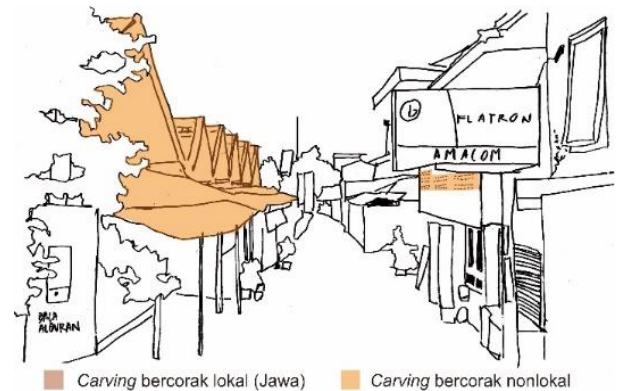

Gambar 22. Carving pada Titik B.2.

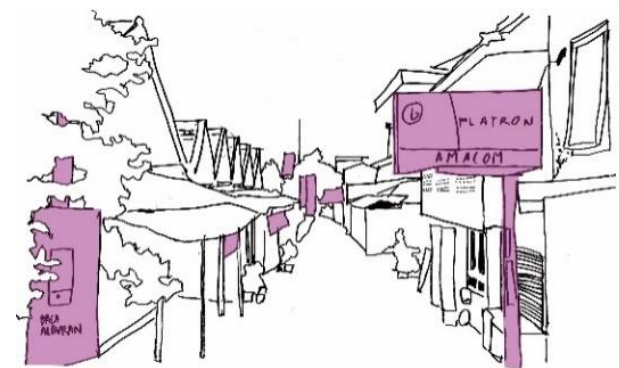

Gambar 23. Streetscape pada Titik B.2.

Ruang terbuka yang berada pada Jalan Samirono CT VI yang tegak lurus dengan Jalan Aster merupakan tempat yang strategis sebagai titik pertemuan. Kepadatan massa pada Titik B.2. diperkirakan mencapai $60 \%$.

Aktivitas berupa dibukanya usaha tempat makan di bagian depan rumah, menjadi activity generator namun belum menimbulkan massa yang berjumlah banyak. Aktivitas yang terlihat berupa lalu lalang kendaraan sepeda motor dan beberapa kursi penunjang fungsi warung, yang pada saat pengamatan warung tersebut sedang tidak beroperasi. Hal ini menandakan adanya aktivitas warung pada waktu-waktu tertentu, tidak di sepanjang waktu.

Potret aktivitas kluwung yang terdokumentasi pada Titik B.2. lantas mengubah panorama bentang kota menjadi meriah dan tidak monoton. Kegiatan kluwung oleh masyarakat Padukuhan Samirono diadakan setahun sekali dengan acara utama melakukan arak-arakan keliling kampung membawa sesaji dan berbaris sambil memakai pakaian adat.

Pada titik pengamatan ini tidak ada carving yang berbentuk sangat nyata seperti ukirukiran tertentu. Carving terbentuk dari repetisi atap tradisional Jawa yaitu atap kampung jompongan. Repetisi ini turut menghasilkan suatu kesan tekstur tertentu.

Bentuk-bentuk streetscape pada Titik B.2. mayoritas terdiri dari signage usaha. Terdapat sebuah spanduk sederhana namun ukup terlihat yang berisi tentang ajakan terhadap masyarakat untuk mengurangi bermain gawai dan lebih membaca (menghayati) Al-Quran. Hal ini mengindikasikan masyarakat secara swadaya menyadari dan mencoba menanggulangi masalah generasi muda setempat dengan tuntunan spiritualitas, khususnya agama Islam.

\subsubsection{ANALISIS RUANG KOTA TITIK B.3.}

Tabel 7. Analisis Ruang Kota Titik B.3.

\begin{tabular}{|c|c|c|c|c|c|c|c|c|c|}
\hline & \multicolumn{2}{|c|}{$\begin{array}{l}\text { Elemen } \\
\text { Natural }\end{array}$} & \multirow{2}{*}{$\begin{array}{c}\text { Space } \\
\text { Organiza } \\
\text { tion }\end{array}$} & \multirow{2}{*}{$\begin{array}{c}\text { Mas } \\
\text { sa }\end{array}$} & \multirow[t]{2}{*}{ Proporsi } & \multicolumn{2}{|c|}{ Aktivitas } & \multirow[t]{2}{*}{$\begin{array}{c}\text { Carvin } \\
g\end{array}$} & \multirow[t]{2}{*}{$\begin{array}{l}\text { Street- } \\
\text { scape }\end{array}$} \\
\hline & V & W & & & & $\mathrm{F}$ & I & & \\
\hline Jalan & +2 & -2 & -1 & +2 & -1 & 0 & -2 & +1 & +1 \\
\hline $\begin{array}{c}\text { Fasad } \\
\text { Bangunan }\end{array}$ & +2 & & & +2 & & 0 & -2 & 0 & 0 \\
\hline Trotoar & & & & & & & & & \\
\hline $\begin{array}{l}\text { Ruang } \\
\text { Terbuka }\end{array}$ & & & & & & & & & \\
\hline Monumen & & & & & & & & & \\
\hline
\end{tabular}




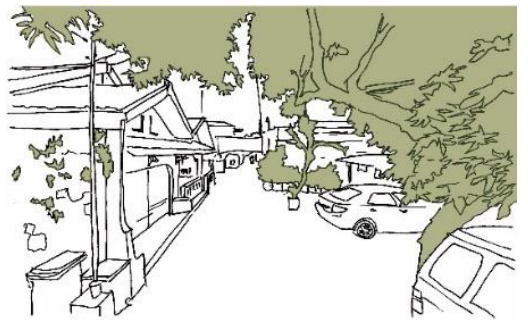

Gambar 24. Vegetasi pada Titik B.3.

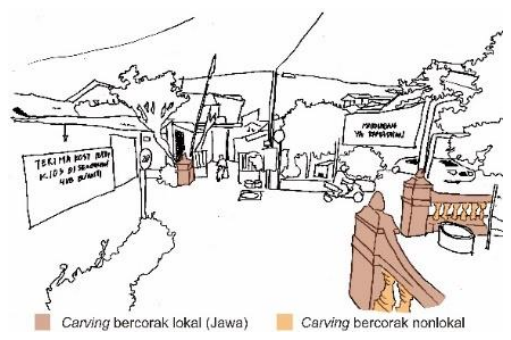

Gambar 25. Carving pada Titik B.3.

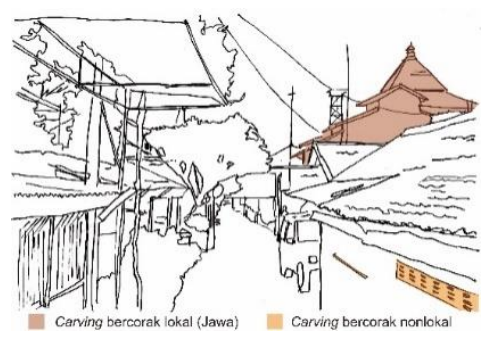

Gambar 26. Carving pada Titik B.3.

Orientasi bidang atap pelana yang menghadap jalan mengakibatkan proporsi bangunan yang bertingkat-tingkat dan mengurangi kesan vertikal nan masif. Tinggi bangunan yang terlihat cukup rendah sehingga bangunan Masjid Jami' Al-Inayah dapat terlihat dengan jelas. Meskipun bangunan masjid berada di luar adiministratif Padukuhan Samirono, bangunan tersebut tetap berpengaruh pada panorama bentang kota pada lingkungan sekitarnya.

Terdapat carving yang terbentuk dari pagar, tapal batas wilayah, dan bentuk atap bangunan Masjid Jami' Al-Inayah. Pagar salah satu rumah yang berada tepat di persimpangan memiliki bentuk menyerupai plengkung dan tapal batas yang ada di sekitarnya, serta memiliki kolom-kolom penyangga dari arsitektur klasik sederhana. Bentuk tersebut cukup unik karena merupakan perpaduan dari beberapa bentuk langgam arsitektur yang berhasil dipadu secara harmonis.

Bentuk atap Masjid Jami' Al-Inayah menggunakan bentuk arsitektur Jawa untuk bangunan masjid yaitu tajug lambang gantung. Masjid tersebut merupakan masjid tingkat kelurahan dan berada di Kelurahan Klitren. Meskipun berada di luar kelurahan lain, namun tetap berpengaruh pada panorama bentang kota di Padukuhan Samirono.

Streetscape pada Titik B.3. terdiri dari tiang listrik, menara suara masjid, cermin, tapal batas, dan spanduk yang berada tepat di perbatasan kelurahan. Spanduk tersebut dikaitkan secara sederhana dan tidak permanen, namun lebih mendefinisikan perbatasan wilayah dibanding dengan tapal batas yang berada di bidang jalan.

\subsubsection{ANALISIS RUANG KOTA TITIK C.1.}

Tabel 8. Analisis Ruang Kota Titik C.1.

\begin{tabular}{|c|c|c|c|c|c|c|c|c|c|}
\hline & \multicolumn{2}{|c|}{$\begin{array}{l}\text { Elemen } \\
\text { Natural }\end{array}$} & \multirow{2}{*}{$\begin{array}{l}\text { Space } \\
\text { Organiza } \\
\quad \text { tion }\end{array}$} & \multirow{2}{*}{$\begin{array}{c}\text { Mass } \\
\text { a }\end{array}$} & \multirow{2}{*}{ Proporsi } & \multicolumn{2}{|c|}{$\begin{array}{c}\text { Aktivit } \\
\text { as }\end{array}$} & \multirow{2}{*}{$\begin{array}{c}\text { Carvin } \\
g\end{array}$} & \multirow{2}{*}{ Street-scape } \\
\hline & $\mathrm{V}$ & W & & & & $\mathrm{F}$ & I & & \\
\hline Jalan & +2 & -2 & -1 & -1 & +1 & -1 & -2 & 0 & +1 \\
\hline $\begin{array}{c}\text { Fasad } \\
\text { Banguna } \\
\mathrm{n}\end{array}$ & +2 & & & -1 & & -1 & -2 & 0 & +1 \\
\hline Trotoar & & & & & & & & & \\
\hline $\begin{array}{l}\text { Ruang } \\
\text { Terbuka }\end{array}$ & & & & & & & & & \\
\hline$\underset{n}{\text { Monume }}$ & & & & & & & & & \\
\hline
\end{tabular}




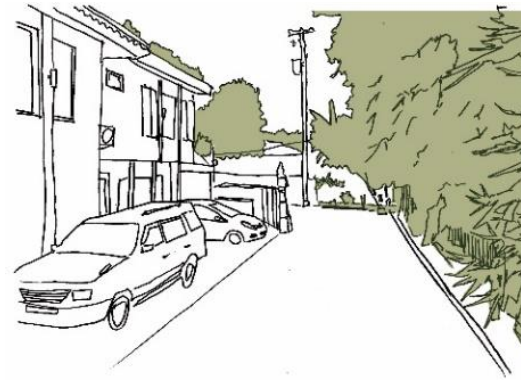

Gambar 27. Vegetasi pada Titik C.1.

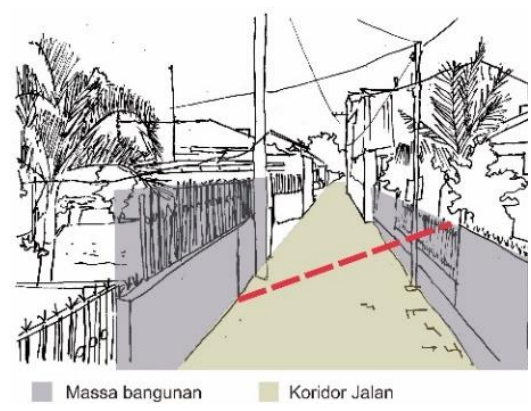

Gambar 28. Proporsi pada Titik C.1.

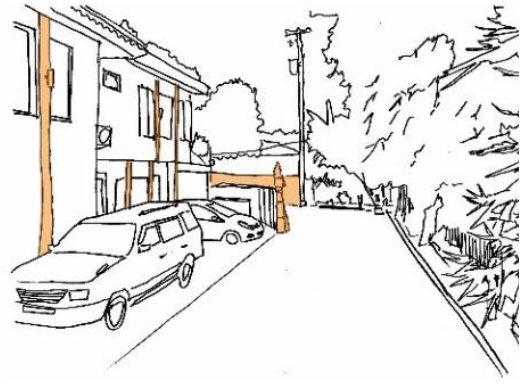

Gambar 29. Carving pada Titik C.1.

Keberadaan elemen natural, khususnya vegetasi cukup banyak dan rimbun sehingga meningkatkan kualitas visual. Rumpun pohon bambu membentuk sebuah bidang dinding vegetasi yang unik dan meningkatkan keindahan panorama bentang kota.

Proporsi lebih dihasilkan oleh pagar daripada bangunan yang ada. Proporsi yang terhasilkan tetap lebih dominan jalan Gambar 26. Vegetasi pada Titik C.1. daripada bangunan. Keberadaan vegetasi turut menyiasati proporsi yang ada menjadi kurang terlihat.

Pagar-pagar mengadopsi material baja dengan bentuk minimalis. Bentuk fasad bangunan terpengaruh dari luar sehingga berbentuk modern dan beberapa yang lain bergaya mediterania. Carving yang terbentuk dari mural dinding bergambarkan komposisi abstrak. Ornamen bangunan indekos menggunakan figur patung penjaga Dwarapala yang merupakan ciri arsitektur Bali.

Sudut yang tercipta akibat berbeloknya koridor jalan mengakibatkan terciptanya sisi jalan yang menarik. Pada sudut ini, terdapat beberapa streetscape pelengkap berupa tiang listrik, pot tanaman, air mancur berbentuk kendi, lampu dengan atap rumah adat bali, dan patung bercorak india kuno (serupa arca Hindu-Buddha). Hal ini menunjukan adanya upaya menghubungkan impresi kebali-balian dari indekos ke bagian sudut jalan tersebut.

\subsubsection{ANALISIS RUANG KOTA TITIK C.2.}

Tabel 9. Analisis Ruang Kota Titik C.2.

\begin{tabular}{|c|c|c|c|c|c|c|c|c|c|}
\hline & \multicolumn{2}{|c|}{$\begin{array}{l}\text { Elemen } \\
\text { Natural }\end{array}$} & \multirow{2}{*}{$\begin{array}{c}\text { Space } \\
\text { Organiza } \\
\text { tion }\end{array}$} & \multirow{2}{*}{$\begin{array}{c}\text { Mass } \\
\text { a }\end{array}$} & \multirow{2}{*}{$\begin{array}{c}\text { Propors } \\
\text { i }\end{array}$} & \multicolumn{2}{|c|}{$\begin{array}{l}\text { Aktivit } \\
\text { as }\end{array}$} & \multirow{2}{*}{$\begin{array}{c}\text { Carvin } \\
g\end{array}$} & \multirow{2}{*}{ Street-scape } \\
\hline & $\mathrm{V}$ & W & & & & $\mathrm{F}$ & I & & \\
\hline Jalan & $\begin{array}{l}+ \\
2 \\
\end{array}$ & -2 & 0 & 0 & 0 & -2 & -3 & +2 & 0 \\
\hline $\begin{array}{c}\text { Fasad } \\
\text { Bangunan }\end{array}$ & $\begin{array}{l}+ \\
2\end{array}$ & & & 0 & & -2 & -3 & +2 & 0 \\
\hline Trotoar & & & & & & & & & \\
\hline $\begin{array}{l}\text { Ruang } \\
\text { Terbuka }\end{array}$ & & & & & & & & & \\
\hline Monumen & & & & & & & & & \\
\hline
\end{tabular}




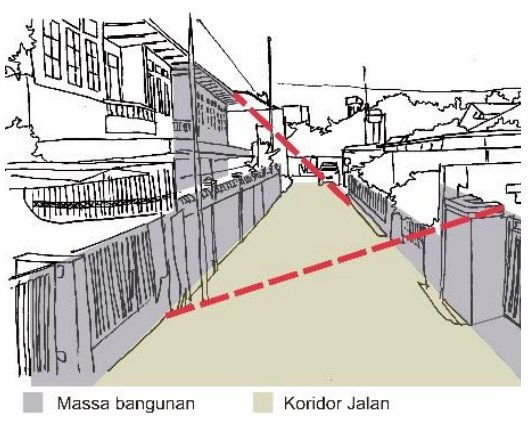

Gambar 30. Proporsi pada Titik C.2.

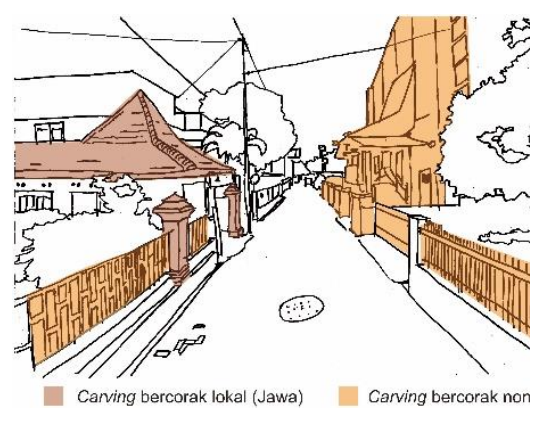

Gambar 31. Carving pada Titik C.2.

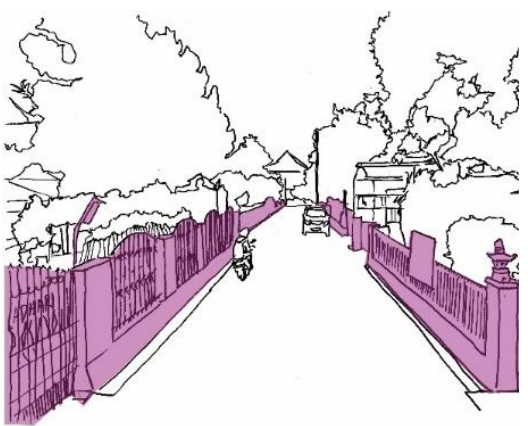

Gambar 32. Carving pada Titik

C.2.

Koridor jalan merupakan jalan utama dan satu-satunya untuk mengakses Gedung Pertemuan Antasari. Pada saat gedung pertemuan aktif maka akan memicu luapan ke jalan ini.

Beberapa bangunan rumah dan bangunan indekos pada koridor ini menggunakan bentuk atap rumah joglo pada massa bangunan yang terpisah dari bangunan utama seperti kios usaha dan garasi mobil.

Terdapat carving yang terbuat dari pagar yang terbuat dari besi-besi ulir yang dekoratif. Bentuk-bentuk atap rumah joglo digunakan hanya pada bangunan penunjang yang berpisah dari massa indekos seperti minniatur atap limasan trajumas dengan bubungan.

Bangunan Gedung Pertemuan Pangeran Antasari merupakan bangunan aset milik pemerintah provinsi Kalimantan Selatan yang difungsikan untuk mewadahi masyarakat dan pelajar asal Kalimantan Selatan yang tinggal di Yogyakarta. Arsitektur bangunan gedung mengadopsi bentuk arsitektur rumah baanjung (rumah tradisional suku Banjar dan suku Dayak Bakumpai) yang diperlihatkan pada fasad bangunan dan ornamen-ornamen, dengan adaptasi modern. Hal ini menjadi suatu keunikan pada panorama bentang kota di koridor tersebut karena justru menerima bentuk arsitektur lokal dari daerah lain.

\subsection{KRITERIA EKSPRESI LOKALITAS}

Elemen Natural. Keberadaan vegetasi pada panorama bentang kota Padukuhan Samirono memiliki intensitas yang berbeda di berbagai tempat. Berdasarkan hasil deskripsi, tidak ada tanda-tanda vegetasi yang ditata untuk menciptakan koridor jalan atau memiliki nilai filosofis tertentu. Jenis vegetasi juga terbatas pada fungsi sekedar menambahkan elemen natural. Namun, elemen vegetasi pada titik-titik pengamatan tertentu berhasil menciptakan kesan dramatis dan meningkatkan potensi sebagai memorable space. Hal ini bertuju pada ekspresi lokalitas dalam ruang lingkup yang kecil, yaitu ruang lingkup Padukuhan Samirono saja.

Space Organization. Tatanan ruang pada Padukuhan Samirono tidak direncanakan untuk menggunakan pakem-pakem tertentu seperti pola geometris atau filosofi spiritual masyarakat. Di sisi lain, pengelompokan fasilitas-fasilitas padukuhan seperti Balai Budaya Samirono, Masjid Al-Ikhlash, Gedung Serbaguna Al-Ikhlash, Taman Pendidikan Al-Quran Al-Ikhlash, dan Madrasah Diniyah Takmiliyah dalam jarak yang berdekatan mengakibatkan terpusatnya kegiatan sosial pada area tersebut. Keberadaan ruang publik yang terbelah oleh jalan berpotensi terjadinya aktivitas yang saling tumpah ruah ke jalan. Fungsi jalan sebagai ruang publik bersama turut menjadi ekspresi lokalitas di panorama bentang kota Padukuhan Samirono. 
Massa. Intensitas kepadatan massa pada Padukuhan Samirono cukup variatif, didominasi oleh kepadatan massa yang tinggi. Perbedaan massa yang kontras menghasilkan pengalaman ruang yang khas.

Proporsi. Selain fasad bangunan berupa bangunan dua lantai dengan balkon di lantai dua dan pagar-pagar, bentuk atap juga menjadi bagian dari proporsi di Padukuhan Samirono. Pada koridor-koridor jalan, atap-atap bangunan serempak membentuk proporsi tidak secara vertikal tegas, melainkan miring mengikuti kemiringan atap.

Bangunan-bangunan publik di Padukuhan Samirono seperti masjid cenderung mendapatkan perlakuan khusus seperti terletak pada lokasi strategis yaitu pada lahan hook. Bangunanbangunan di sekitarnya juga cenderung merendah, sehingga bangunan-bangunan publik tersebut semakin jelas terlihat. Hal ini merupakan bagian dari ekspresi masyarakat untuk mengistimewakan bangunan publik milik bersama. Di sisi lain, bentuk atap masjid tidak mencirikan lokalitas Jawa seperti atap tajug dan ornamen lokal, tetapi mengadopsi arsitektur dari luar dengan atap datar dan atap kubah.

Aktivitas. Aktivitas keseharian di Padukuhan Samirono cenderung sepi. Aktivitas kluwung yang menjadi kegiatan rutin tahunan menjadi bagian dari cara masyarakat berekspresi menyuarakan eksistensinya. Acara pawai berkeliling kampung dengan pakaian adat memengaruhi panorama bentang kota menjadi meriah dan berekspresi lokalitas.

Carving. Selain carving bergaya modern, carving dengan corak lokalitas Jawa juga muncul dalam bentuk pagar-pagar yang menyerupai plengkung. Ornamen-ornamen khas tradisional Jawa jarang ditemui, sehingga bangunan Balai Budaya yang berbentuk rumah adat joglo terlihat sangat istimewa.

Streetscape. Streetscape berupa tapal batas dan gapura entrance padukuhan cukup terhalang oleh keberadaan objek lain. Spanduk-spanduk yang ada pada fasad bangunanbangunan kebanyakan bertujuan komersial. Spanduk-spanduk bernuansa keagamaan juga kerap ditemui berisi ajakan generasi muda untuk lebih taat beribadah. Hal ini merupakan suatu ekspresi masyarakat yang berupaya untuk menanamkan nilai-nilai kegamaan sebagai bagian dari tanggung jawab bersama.

\section{KESIMPULAN}

Pada Padukuhan Samirono, lokalitas tidak hadir secara visual seperti pada umumnya, melainkan dalam bentuk adaptasi rupa. Contoh-contohnya seperti abstraksi plengkung yang menjadi pagar, dan aktivitas kluwung yang menunjukan semangat persatuan masyarakat. Kekuatan aktivitas kluwung secara cepat dapat mengubah panorama bentang kota menjadi meriah dan berekspresi lokalitas. Hal ini merupakan tanda bahwa Padukuhan Samirono tetap berusaha menerapkan lokalitas pada citra yang sepenuhnya modern.

Panorama bentang kota yang berciri lokalitas dapat semakin pudar dari waktu ke waktu. Diperlukan kerja sama antara masyarakat dan perencana untuk tetap mempertahankan ekspresi lokal, sehingga lokalitas pada suatu kawasan akan semakin berkembang seiring dengan perubahan zaman.

\section{DAFTAR PUSTAKA}

ASHIHARA, Y. (1983). The Aesthetic Townscape. Cambridge: MIT Press.

BAWOLE, P. (2009, Juni 23). Masyarakat Kampung Mampu Siasati Keterbatasan Ruang. Kompas.

BURGER, D. H. (1983). Perubahan-Perubahan Struktur dalam Masyarakat Jawa. Jakarta: Bhratara.

CANTER, D. V. (1975). Psychology for Architects. New York: Wiley.

CULLEN, G. (1971). The Concise Townscape. Oxford: Architectural Press. 
ELTSANY, S. (2017). Hunian Bertingkat di Samirono dengan Solatube sebagai Pendekatan Perancangan Pencahayaan Alami untuk Antisipasi Mikroba. Proyek Akhir Sarjana, Departemen Arsitektur, Fakultas Teknik dan Perencanaan, Universitas Islam Indonesia.

FATUROCHMAN. (1990, Mei 30-31). Kondisi Sosio-Psikologis Yogya Unik. Yogya Post.

KOMPAS. (2009, Juni 23). Masyarakat Kampung Mampu Siasati Keterbatasan Ruang.

LYNCH, K. (1960). The Image of The City. Cambridge: MIT Press.

MCCLUSKY, J. (1979). Road Form and Townscape. Oxford: Architectural Press.

MUCHAMAD, B. N., \& Ikaputra. (2010). Model Ekspresi Arsitektur. Seminar Nasional "Metodologi Riset dalam Arsitektur", 1-8.

PANGARSO, F.X. Budi Widodo. (2020). Pengantar Estetika Perkotaan. Diktat Perkuliahan. Bandung: Tidak Diterbitkan.

SURYANDARI, P. (2007). Geliat Nafas Kampung Kota Sebagai Bagian dari Permukiman Kota. Jurnal..., 54-72.

WIDAYAT, R. (2010, November 4). Estetika Jawa dalam Konteks Desain Interior dan Arsitektur. In J. Sumardjo, Estetika Nusantara (pp. 92-107). Surakarta: Insitut Seni Indonesia 